\title{
Chrysiogenes arsenatis gen. nov., sp. nov., a New Arsenate-Respiring Bacterium Isolated from Gold Mine Wastewater
}

\author{
JOAN M. MACY, ${ }^{*}{ }^{*}$ KATRINA NUNAN,${ }^{1}$ KARI D. HAGEN,${ }^{2}$ DAVID R. DIXON, ${ }^{3}$ PETER J. HARBOUR, ${ }^{3}$ \\ MARIAN CAHILL, ${ }^{4}$ AND LINDSAY I. SLY ${ }^{4}$ \\ School of Microbiology, La Trobe University, Bundoora, Victoria, 3083, ${ }^{1}$ Division of Chemicals and Polymers, \\ Commonwealth Scientific and Industrial Research Organization, Clayton, Victoria, $3168,{ }^{3}$ and Center for Bacterial \\ Diversity and Identification, Department of Microbiology, University of Queensland, Brisbane, Queensland, 4072, ${ }^{4}$ \\ Australia, and Department of Microbiology, University of California, Davis, California $95616^{2}$
}

\begin{abstract}
A new strictly anaerobic bacterium (strain BAL-1 ${ }^{\text {T }}$ ) has been isolated from a reed bed at Ballarat Goldfields in Australia. The organism grew by reducing arsenate [As(V)] to arsenite [As(III)], using acetate as the electron donor and carbon source; acetate alone did not support growth. When BAL-1 ${ }^{\mathrm{T}}$ was grown with arsenate as the terminal electron acceptor, acetate could be replaced by pyruvate, $L$ - and $D$-lactate, succinate, malate, and fumarate but not by $\mathrm{H}_{2}$, formate, citrate, glutamate, other amino acids, sugars, or benzoate. When acetate was the electron donor, arsenate could be replaced by nitrate or nitrite but not by sulfate, thiosulfate, or iron oxide. Nitrate was reduced to ammonia via nitrite. The doubling time for growth on acetate $(5 \mathrm{mM})$ plus arsenate $(5 \mathrm{mM})$ or nitrate $(5 \mathrm{mM})$ was $4 \mathrm{~h}$. The $\mathrm{G}+\mathrm{C}$ content of the DNA is $49 \mathrm{~mol} \%$. The $16 \mathrm{~S}$ rRA sequence data for the organism support the hypothesis that this organism is phylogenetically unique and at present is the first representative of a new deeply branching lineage of the Bacteria. This organism is described as Chrysiogenes arsenatis gen. nov., sp. nov.
\end{abstract}

A number of different bacteria are able to protect themselves from arsenic. They do so by first reducing arsenate $[\mathrm{As}(\mathrm{V})]$ that has entered the cell to arsenite $[\mathrm{As}(\mathrm{III})]$ and then transporting the arsenite out of the cell; arsenate reduction does not appear to support growth $(7,20)$. Reduction of arsenate to arsenite in anoxic environments has also been demonstrated $(3,15)$, but until recently the organisms responsible for this reduction and the mechanisms used were not known.

In 1994 a new isolate was described in a scientific correspondence in Nature (1). This organism, strain MIT-13, when grown in the absence of oxygen was found to use arsenate as a terminal electron acceptor during growth on lactate as the electron donor and carbon source. The lactate was presumably oxidized to acetate, but not completely to $\mathrm{CO}_{2}$, as the respiratory compound acetate could not be used as a substrate for growth (1). The doubling time for growth on $10 \mathrm{mM}$ arsenate was approximately $14 \mathrm{~h}$. Strain MIT-13, which resembles morphologically Desulfovibrio species, could also grow on lactate using sulfate as the terminal electron acceptor (1).

More recently, strain SES-3, isolated first as a selenatereducing bacterium, was found to reduce arsenate to arsenite when grown in the absence of oxygen and when using lactate as the electron donor and carbon source; the lactate was oxidized to acetate (11). The doubling time when this strain was grown with $5 \mathrm{mM}$ arsenate was about $5 \mathrm{~h}$. Like strain MIT-13, strain SES-3 was unable to grow using acetate as the electron donor.

Arsenate-dependent anaerobic growth by a pure culture with the respiratory substrate acetate as the electron donor has not yet been reported, although acetate-dependent arsenate reduction in anoxic sediments has recently been demonstrated (3). We describe here a newly isolated strictly anaerobic organism that can grow with acetate as the electron donor only if arsenate, nitrate, or nitrite is present as the terminal electron acceptor; sulfate and $\mathrm{Fe}$ (III) do not function as terminal electron acceptors. The arsenate is reduced to arsenite. Since

* Corresponding author. Phone: (03)-9479-2229. Fax: (03)-94791222. Electronic mail address: micjm1@LURE.LATROBE.EDU.AU.
BAL- $1^{\mathrm{T}}$ is able to grow in a minimal medium with arsenate as the electron acceptor and the respiratory substrate acetate as the electron donor, this new arsenate-reducing bacterium can apparently conserve energy using arsenate respiration. In addition, the $16 \mathrm{~S}$ rRNA sequence of this isolate is consistent with the hypothesis that this organism is phylogenetically unique.

\section{MATERIALS AND METHODS}

Growth media and conditions. The anoxic minimal medium described previously (14) was used, except that the sulfate concentration was $0.03 \mathrm{mg} / \mathrm{liter}$. In enrichment cultures and when cultures were purified in agar medium (Oxoid purified agar, $1.5 \%)$ a reducing agent $(0.03 \%$ cysteine) was present, and the concentration of arsenate and acetate was $10 \mathrm{mM}$. When carrying out growth experiments the minimal medium contained acetate $(5 \mathrm{mM})$ and arsenate $(5$ $\mathrm{mM}$ ); cysteine-HCl was not present. When substrates used for growth were tested, the medium contained an electron acceptor $(5 \mathrm{mM})$ plus an electron donor $(5 \mathrm{mM})$; cysteine- $\mathrm{HCl}$ was not present in the medium. The standard anaerobic culture technique of Hungate was used for all of these experiments (14). All incubations were done at $28^{\circ} \mathrm{C}$.

Enrichments. Anoxic enrichments were made in a minimal medium by using mud obtained from a reed bed near the Ballarat Goldfields in Ballarat, Australia, as the inoculum (14); the reducing agent added was $0.03 \%$ cysteine- $\mathrm{HCl}$, and the medium contained arsenate $(10 \mathrm{mM})$ and acetate $(10 \mathrm{mM})$. Enrichments were incubated for 6 days at $28^{\circ} \mathrm{C}$. The enrichment was subcultured twice. A very motile, small, curved rod, designated $\mathrm{BAL}-1^{\mathrm{T}}$, was isolated from the third enrichment subculture, using the same anaerobic medium containing $1.5 \%$ Oxoid purified agar in Hungate roll tubes (14). This organism has been deposited with the American Type Culture Collection as strain ATCC 700172. The organism has been maintained by subculturing once a week on average in minimal medium containing acetate $(5$ or $10 \mathrm{mM})$ plus arsenate $(5$ or $10 \mathrm{mM})$; cysteine- $\mathrm{HCl}$ was not present in the medium.

Growth of BAL-1 ${ }^{\mathrm{T}}$ on acetate and arsenate. BAL- $1^{\mathrm{T}}$ was grown in $400 \mathrm{ml}$ of anoxic minimal medium plus acetate $(3$ to $5 \mathrm{mM}$ ) and arsenate ( 3 to $5 \mathrm{mM}$ ). The $\mathrm{pH}$ was maintained at 7.4 to 7.8 by the addition of $100 \mathrm{mM} \mathrm{HCl}$. The inoculum was $40 \mathrm{ml}$ of an overnight culture grown in the same medium (without $\mathrm{pH}$ control). The concentration of total arsenic [As(V) plus As(III)] remained constant throughout the experiment. Prior to its use in growth experiments, BAL- ${ }^{\mathrm{T}}$ had been subcultured and grown in minimal medium, containing only arsenate ( 5 or $10 \mathrm{mM}$ ) and acetate ( 5 or $10 \mathrm{mM})$, at least 50 times; cysteine was not present in the medium. Growth experiments were carried out on five separate occasions; the results of one of these experiments are presented here. Initially, experiments were performed without $\mathrm{pH}$ control; however, the $\mathrm{pH}$ rose to 9.4 during growth and arsenate reduction (see the equation in Discussion; protons are consumed during arsenate reduction to arsenite with acetate as the electron donor), and growth ceased when cell numbers had reached $10^{8} / \mathrm{ml}$.

Electron donors and electron acceptors used for growth. The electron accep- 
tors tested for their ability to support growth, when acetate was present as the electron donor, included arsenate $(5 \mathrm{mM})$, nitrate $(5 \mathrm{mM})$, nitrite $(5 \mathrm{mM})$, sulfate $(5 \mathrm{mM})$, thiosulfate $(5 \mathrm{mM}), \mathrm{Fe}$ (III) (used as described by Lovley and Phillips [12]), selenate (5 mM), and oxygen (added as $10 \mathrm{ml}$ of air to a closed $20-\mathrm{ml}$ roll tube containing $10 \mathrm{ml}$ of medium). The electron donors tested (all at $5 \mathrm{mM}$, except molecular hydrogen, of which $10 \mathrm{ml}$ was added) for their ability to support growth when arsenate or nitrate was present as the electron acceptor included formate, molecular hydrogen, acetate, pyruvate, lactate, fumarate, malate, succinate, citrate, selected amino acids (glutamate, threonine, aspartate, serine, phenylalanine, arginine, valine, and histidine), methanol, glucose, fructose, sucrose, ribose, xylose, and benzoate. Standard anaerobic cultivation methods were used throughout these experiments (14). The initial BAL- $1^{\mathrm{T}}$ inoculum used for these experiments had been grown in minimal medium containing acetate $(5 \mathrm{mM})$ plus arsenate $(5 \mathrm{mM})$. Growth with a given electron acceptor was considered positive only if at least $90 \%$ of the electron acceptor had been reduced, after at least three subsequent subcultures.

Since good growth (i.e., an increase in the number of motile bacteria from about $5 \times 10^{6} / \mathrm{ml}$ to at least $10^{8} / \mathrm{ml}$ in non-pH-controlled cultures) was observed only in cultures where either nitrate or arsenate was the terminal electron acceptor (nitrite supported only slight growth, with numbers reaching only about $5 \times 10^{7} / \mathrm{ml}$ ), the ability of BAL-1 ${ }^{\mathbf{T}}$ to grow with various electron donors was determined by using only these two electron acceptors. Growth on a given electron donor was considered positive only if the numbers of motile organisms had increased from about $5 \times 10^{6}$ to $10^{8} / \mathrm{ml}$ after at least three subsequent subcultures and if at least $90 \%$ of the nitrate or arsenate present in the culture initially had been reduced to nitrite plus ammonia or to arsenite. In cultures where arsenate was reduced to arsenite, the total amount of arsenic in cultures remained constant throughout the experiment.

Analyses. The concentrations of total arsenic [As(III) plus As(V)] and arsenite [As(III)] were determined as described in references 6 and 24, using a Varian Spectra AA20 atomic absorption spectrophotometer for detection of the arsenic hydrides. A model VGA-76 hydride generator was used. Nitrate and nitrite were analyzed as described previously $(13,19)$. Ammonia was measured using the method of Bower and Holm-Hansen (2). Acetate was analyzed as described previously (13).

Electron microscopy. Cells were negatively stained with $1 \%$ uranyl acetate in $0.4 \%$ sucrose and were viewed and photographed with a Zeiss EM 109 transmission electron microscope.

DNA base composition. Genomic DNA was extracted and the melting temperature was determined by the method of Nelson et al. (16). Strain BAL-1 ${ }^{\mathrm{T}}$ was grown in minimal medium plus $0.4 \%$ yeast extract, $10 \mathrm{mM}$ nitrate, and $10 \mathrm{mM}$ acetate at $28^{\circ} \mathrm{C}$. Cells were collected by centrifugation at $10,000 \times \mathrm{g}$ for $15 \mathrm{~min}$. DNA isolated from Escherichia coli K-12 ATCC 10798 and Pseudomonas aenuginiosa ICPB 2524 were used as controls; both organisms were grown in nutrient broth (Difco) at $37^{\circ} \mathrm{C}$, and cells were harvested as before. Cells were disrupted in a French press $\left(16,000 \mathrm{lb} / \mathrm{in}^{2}\right.$; American Instrument Company, Silver Spring, Md.). The DNA from each resulting cell extract was extracted and purified, and the melting temperature was determined and used to calculate the $\mathrm{G}+\mathrm{C}$ content (in moles percent) as described by Nelson et al. (16).

16S rRNA sequence determination. Cells were grown as described above (with $5 \mathrm{mM}$ arsenate and $5 \mathrm{mM}$ acetate), centrifuged for $30 \mathrm{~min}$ at $8,000 \times \mathrm{g}$, suspended in $2 \mathrm{ml}$ of minimal medium lacking acetate and arsenate, and then centrifuged for $5 \mathrm{~min}$ in a microcentrifuge. The pellet was resuspended in $50 \mu \mathrm{l}$ cf sterile water. This suspension was heated at $95^{\circ} \mathrm{C}$ for $15 \mathrm{~min}$ to release the DNA. The heated suspension $(1 \mu \mathrm{l})$ was then used for amplification of the ribosomal DNA gene by PCR as described by Rainey et al. (18). The PCR products were purified by adding 95 to $100 \mu \mathrm{l}$ of direct purification buffer (50 $\mathrm{mM} \mathrm{KCl}, 10 \mathrm{mM}$ Tris-HCl [pH 8.8 at $25^{\circ} \mathrm{C}$ ], $1.5 \mathrm{mM} \mathrm{MgCl}_{2}, 0.1 \%$ Triton X-100) (Magic PCR Preps DNA purification system; Promega Corporation) and then using the Promega Wizard Minipreps DNA purification system according to the manufacturer's instructions. The purified PCR product was used as a template for automated sequencing on an Applied Biosystems 373A DNA sequencer. The 16S ribosomal DNA sequencing primers used were as follows (E. coli numbering): 342r, 5'CTGCTGCCTCCCGTAG; 357f, 5'CTCCTACGGGAGGCAGC $\mathrm{AG}$; 519r, 5'GWATTACCGCGGCKGCTG; 530f, 5'GTGCCAGCMGCCGC GG; 787r，5'CTACCAGGGTATCTAAT; 803f, 5'ATTAGATACCCTGGT; 1224f, 5'TACACACGTGCTACAATG; and 1392r, 5'ACGGGCGGTGTGTRC $(\mathrm{K}=\mathrm{G}$ or $\mathrm{T}, \mathrm{M}=\mathrm{C}$ or $\mathrm{A}, \mathrm{R}=\mathrm{A}$ or $\mathrm{G}, \mathrm{W}=\mathrm{A}$ or $\mathrm{T}$ ) (9). The 16S rRNA sequence of strain $\mathrm{BAL}-1^{\mathrm{T}}$ was aligned manually against representative bacterial 16S rRNA sequences obtained from the NSF Ribosomal RNA Database (10 17). Pairwise evolutionary distances were computed by the method of Jukes and Cantor (8) with the DNADIST program in the PHYLIP 3.4 software package (4). Positions where length and sequence variations made alignment uncertain and where there was less than $50 \%$ consensus (25) were omitted. The final analysis included 1,018 bases. Phylogenetic dendrograms were constructed by the neighbor-joining method of Saitou and Nei (22), and also by the parsimony method by using DNAPARS in PHYLIP (4). Bootstrap analysis was performed to determine the statistical significance of the branching patterns of trees produced by both neighbor-joining and parsimony analyses by using the statistical programs SEQBOOT and CONSENSE from the PHYLIP 3.4 software package (4). The sequence of Methanosarcina barkeri was used as the outgroup in phylogenetic analyses.
Nucleotide sequence accession number. The sequence determined in this study for BAL- ${ }^{\mathrm{T}}$ has been deposited in EMBL under the accession number X81319.

\section{RESULTS}

Isolation. Predominant in all enrichments was a small, curved, motile, rod-shaped bacterium. The organism isolated, designated $\mathrm{BAL}-1^{\mathbf{T}}$, is a gram-negative, strictly anaerobic, curved, rod-shaped bacterium with a single polar flagellum (Fig. 1).

Growth with acetate plus arsenate. Growth of BAL-1 ${ }^{\mathrm{T}}$ in minimal medium containing acetate $(3.9 \mathrm{mM})$ as the electron donior and arsenate $(3.6 \mathrm{mM})$ as the electron acceptor is shown in Fig. 2. BAL- $1^{\mathrm{T}}$ reduces arsenate to arsenite while using acetate as the electron donor. The level of total arsenic (i.e., arsenate plus arsenite) remained constant throughout growth. The generation time during growth was $4 \mathrm{~h}$. Growth ceased when all of the arsenate had been reduced. On the basis of data in Fig. 3, the stoichiometry of acetate consumption and arsenite production was about 4 . Growth did not occur when either arsenate (Fig. 3) or acetate (data not shown) was absent from the medium.

Growth characteristics. When BAL-1 ${ }^{\mathrm{T}}$ was grown in minimal medium with arsenate $(5 \mathrm{mM})$ as the terminal electron acceptor, the following electron donors and carbon sources supported growth: acetate, pyruvate, L- and D-lactate (growth with D-lactate was greater than that with L-lactate), fumarate, succinate, and malate. No growth occurred on any of these substrates when arsenate was absent. Hydrogen, formate, citrate, glutamate, threonine, aspartate, serine, phenylalanine, arginine, valine, histidine, methanol, glucose, fructose, sucrose, ribose, xylose, and benzoate did not support growth in the presence of arsenate.

When BAL- $1^{\mathrm{T}}$ was grown with acetate $(5 \mathrm{mM})$ as the electron donor and carbon source, only nitrate $(5 \mathrm{mM})$ and nitrite $(5 \mathrm{mM})$ could replace arsenate as the terminal electron acceptor. The electron acceptors sulfate, thiosulfate, Fe(III), selenate, and oxygen did not support growth. Growth with sulfate plus lactate did not occur.

$16 \mathrm{~S}$ rRNA sequence analysis. The full $16 \mathrm{~S}$ rRNA sequence of strain BAL-1 ${ }^{\mathrm{T}}$ was determined. The analysis of almostcomplete 16S rRNA sequences showed that strain BAL-1 ${ }^{\mathrm{T}}$ branched deeply with "Flexistipes sinusarabici," an anaerobic, gram-negative, flexible, rod-shaped thermophilic bacterium isolated from brine water samples of the Red Sea at a depth of 2,000 m (5), and Synechococcus sp. strain 6301 (Fig. 4). The analysis of binary similarity data indicated that the 16S rRNA sequence of strain BAL-1 ${ }^{\mathrm{T}}$ has only 74.8 to $81.8 \%$ similarity with the sequences of representatives of all other major phylogenetic groups within the Bacteria. The phylogenetic relationship of strain BAL- $1^{\mathrm{T}}$ with the phyla of the Bacteria is shown in Fig. 4. Comparison of the BAL- ${ }^{\mathrm{T}} 16 \mathrm{~S}$ rRNA sequence with those of the major phyla of the Bacteria showed that the highest similarities are with Lactobacillus casei $(81.8 \%)$, “F. sinusarabici" (81.7\%), Bacillus subtilis $(81.7 \%)$, and a Synechococcus sp. $(81 \%)$. Bootstrap analysis showed that some deep branching points were statistically unstable. When the neighbor-joining method was used, the branch including strain BAL-1", " $F$. sinusarabici" and the Synechococcus sp. and that joining BAL- ${ }^{\mathrm{T}}$ and " $F$. sinusarabici" occurred in 36 and $50 \%$ of trees, respectively. Bootstrap analysis of trees created by using DNAPARS also showed strain BAL-1 ${ }^{\mathrm{T}}$ branching with the Synechococcus $\mathrm{sp}$. and "F. sinusarabici," but in fewer $(28 \%)$ trees, while the branch joining strain BAL-1 ${ }^{\mathrm{T}}$ and " $F$. sinusarabici" occurred in $44.3 \%$ of these trees. The 

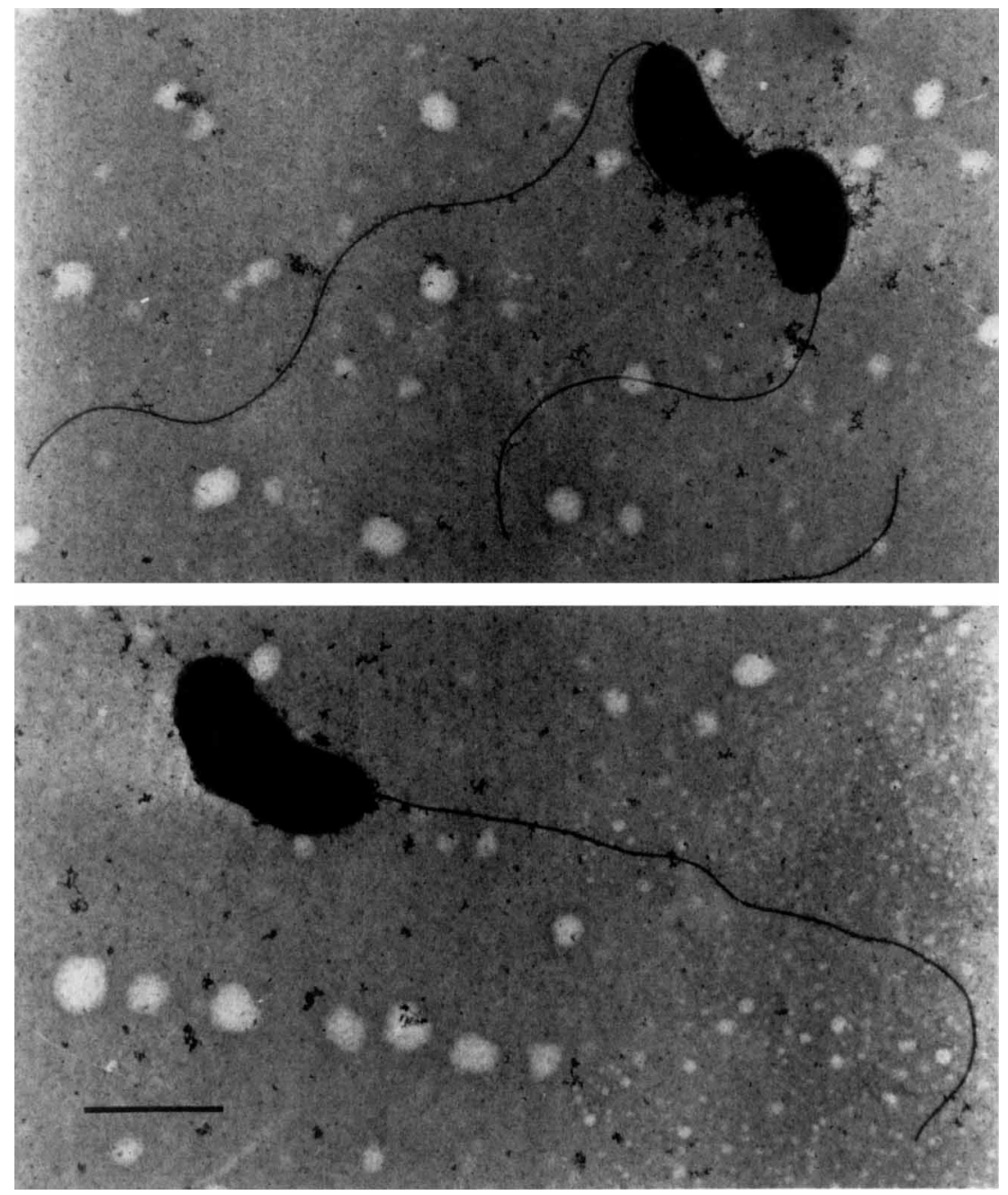

FIG. 1. Electron micrograph of BAL-1 ${ }^{\mathrm{T}}$ grown anaerobically in minimal medium plus acetate $(5 \mathrm{mM})$ and arsenate $(5 \mathrm{mM})$. Bar $=1 \mu \mathrm{m}$.

variation in percentages of trees showing a particular branching pattern is characteristic of the use of different algorithms. The low percentages illustrate the instability of the deep branching points of the phylogenetic tree, even when established representatives of bacterial groups were used for comparison with the new strain.

Comparison of the BAL- ${ }^{\mathrm{T}} 16 \mathrm{~S}$ rRNA sequence with the eubacterial consensus sequence (conserved in $95 \%$ or more of eubacterial 16S rRNAs) (9) showed that the sequence of BAL- ${ }^{\mathbf{T}}$ differed from the consensus at four positions (the base in the eubacterial consensus is given first): position 607 (A versus $\mathrm{U}$ ); position 678 ( $\mathrm{U}$ versus $\mathrm{G}$ ); position 712 (A versus $\mathrm{U})$; and position 1159 (U versus A). Positions 678 and 712 are complementary, so that a U-A pair is replaced by G-U.

\section{DISCUSSION}

Strain BAL- $1^{\mathrm{T}}$ is a physiologically unique bacterium and differs from the two known arsenate-reducing bacteria (MIT-13 and SES-3) in its ability to grow with the respiratory substrate acetate as the electron donor $(1,11)$. Neither strain MIT-13 nor strain SES-3 is able to use acetate as the electron donor for the reduction of arsenate; instead, they grow by using lactate $(1,11)$. The ability of BAL- $1^{\mathrm{T}}$ to use the respira-

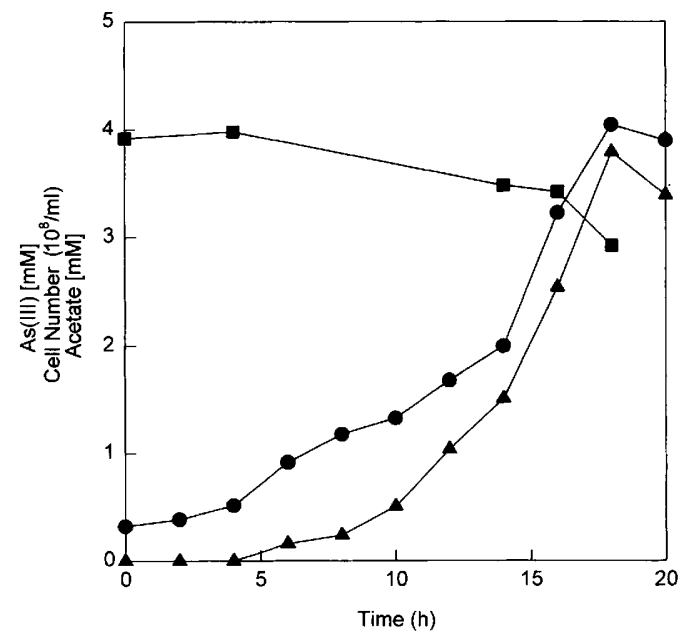

FIG. 2. Growth of BAL-1 ${ }^{\mathrm{T}}$ in minimal medium with arsenate $(5 \mathrm{mM})$ and acetate $(5 \mathrm{mM})$. The culture $(400 \mathrm{ml})$ was inoculated with an overnight culture $(40 \mathrm{ml})$ of BAL $-1^{\mathrm{T}}$ grown in minimal medium with acetate $(5 \mathrm{mM})$ and arsenate $(5 \mathrm{mM})$. The $\mathrm{pH}$ was maintained at 7.4 to 7.8 . concentration; $\mathbf{b}$, acetate concentration. 


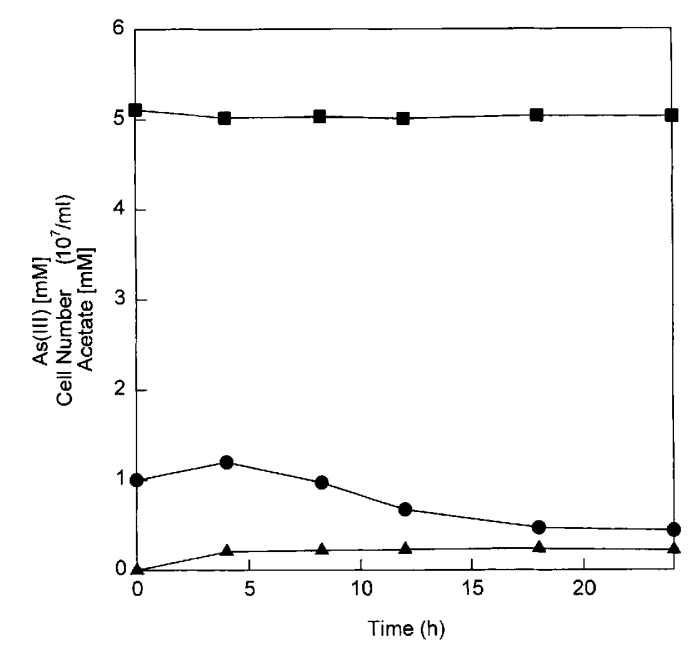

FIG. 3. Growth of BAL- $1^{\mathrm{T}}$ in minimal medium with acetate $(5 \mathrm{mM})$. The culture $(400 \mathrm{ml})$ was inoculated with an overnight culture $(40 \mathrm{ml})$ of BAL-1 ${ }^{\mathrm{T}}$ grown in minimal medium with acetate $(5 \mathrm{mM})$ and arsenate $(5 \mathrm{mM})$. The $\mathrm{pH}$ was maintained at 7.4 to 7.8 . $\mathbf{\theta}$, cell number; $\boldsymbol{\Delta}$, arsenite concentration; $\mathbf{\square}$, acetate concentration.

tory substrate acetate as the electron donor and carbon source for growth, when reducing arsenate to arsenite, suggests that arsenate respiration supports the growth of this organism. The finding of Dowdle et al., who demonstrated that arsenate is

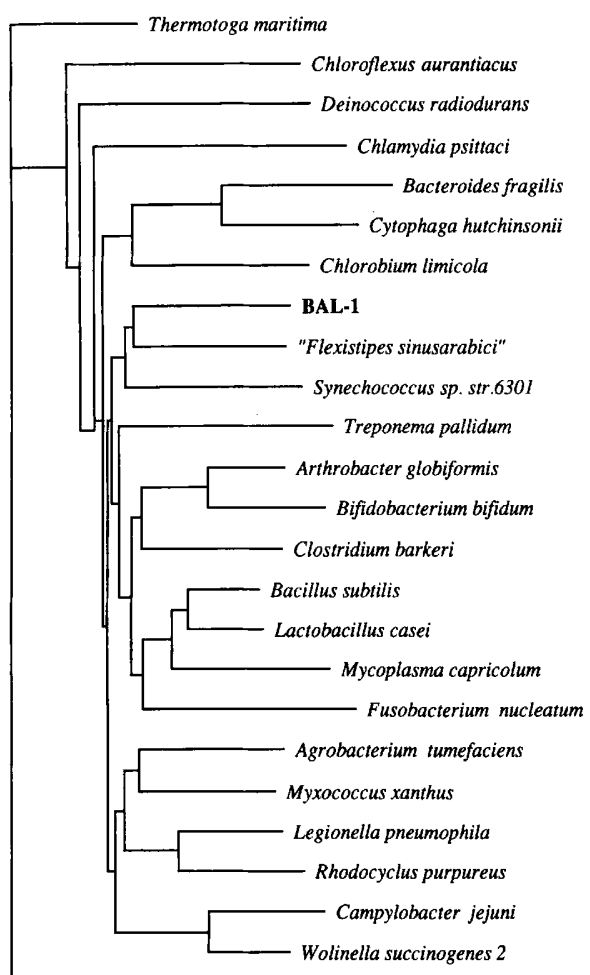

Methanosarcina barkeri

0.10

FIG. 4. Phylogenetic neighbor-joining dendrogram showing the relationships of strain $\mathrm{BAL}-\mathrm{1}^{\mathrm{T}}$ with representatives of the phyla of Bacteria. Bar $=0.1 \%$ sequence difference. reduced to arsenite in anoxic environments when acetate is present as the electron acceptor, supports the existence of organisms such as BAL-1 ${ }^{\mathrm{T}}(3)$.

In addition to using arsenate as the terminal electron acceptor, BAL- ${ }^{\mathrm{T}}$ can also use nitrate or nitrite. Strain MIT-13 can use either arsenate or sulfate (1), while SES-3 also uses selenate, $\mathrm{Fe}$ (III), thiosulfate, elemental sulfur, $\mathrm{Mn}$ (IV), nitrite, trimethylamine $\mathrm{N}$-oxide, or fumarate (11).

The 16S rRNA data support the conclusion that $\mathrm{BAL}-1^{\mathrm{T}}$ is phylogenetically unique and at present is the first sequenced representative of a new deeply branching lineage of the $\mathrm{Bac}$ teria. The nearest relative of BAL-1 ${ }^{\mathrm{T}}$ is " $F$. sinusarabici" (Fig. 4), which is an anaerobic, gram-negative, flexible, rod-shaped, thermophilic bacterium isolated from brine water samples of the Red Sea at a depth of $2,000 \mathrm{~m}$ (5). This organism is physiologically different from the arsenate-reducing bacterium. The phylogenetic positions of strains MIT-13 and SES-3 are not known at present.

Apart from BAL-1 ${ }^{\mathrm{T}}$, MIT-13, and SES-3, the only other bacteria known to reduce arsenate do so as part of a mechanism used to protect themselves from this compound. Arsenate-resistant isolates of both E. coli and Staphylococcus aureus transport this oxyanion into the cell, reduce it to arsenite, and then transport the arsenite out of the cell (7). Arsenate reduction by these organisms presumably does not support growth, although this reaction can potentially yield energy:

$$
\begin{aligned}
2 \mathrm{HAsO}_{4}{ }^{2-} & +2 \mathrm{H}_{2} \mathrm{AsO}_{4}{ }^{-}+5 \mathrm{H}^{+}+\mathrm{CH}_{3} \mathrm{COO} \\
\rightarrow & 4 \mathrm{H}_{3} \mathrm{AsO}_{3}+2 \mathrm{HCO}_{3}^{-}
\end{aligned}
$$

(at pH $7, \Delta \mathrm{G}^{0^{\prime}}=-252.6 \mathrm{~kJ} / \mathrm{mol}$ of acetate) $(21,23)$

It will be interesting to compare the arsenate reductase enzyme of BAL $-1^{\mathrm{T}}$ and the genes encoding this enzyme with the enzymes and genes of the $E$. coli and $S$. aureus arsenic resistance systems.

In conclusion, BAL- $1^{\mathrm{T}}$ is both physiologically and phylogenetically unique and is the first representative of a new deeply branching lineage of the Bacteria for which we propose the name Chrysiogenes arsenatis gen. nov., sp. nov.

Description of Chrysiogenes gen. nov. Chrysiogenes (chry.si.o'ge.nes; Gr. n. chryseion, gold mine; Gr. patronymic suff. -genes, sprung from, born from; N. L. masc. n. Chrysiogenes, sprung from a gold mine, because it was discovered at a gold mine). Gram-negative, curved, rod-shaped cells are 1.0 to $2.0 \mu \mathrm{m}$ long and 0.50 to $0.75 \mu \mathrm{m}$ wide, with rounded ends. Cells are motile, each with a single polar flagellum. Strictly anaerobic. Grows in defined media containing acetate as the carbon source and electron donor. Exhibits anaerobic respiration with arsenate, nitrate, or nitrite as the electron acceptor. Arsenate is reduced to arsenite. Nitrate is reduced to nitrite and ammonia. Acetate is metabolized to $\mathrm{CO}_{2}$. Growth is also supported by the carbon and energy sources pyruvate, L-lactate, D-lactate, malate, fumarate, and succinate. Vitamins are not required for growth in a defined medium. In agar, colonies are small, round with entire edges, convex, and white. Optimal growth occurs at 25 to $30^{\circ} \mathrm{C}$. The base composition of the DNA of the type strain of the type species is $49 \mathrm{~mol} \% \mathrm{G}+\mathrm{C}$ (as determined by the thermal denaturation method). Phylogenetically, the genus is the first representative of a new deeply branching lineage of the Bacteria. The type species is Chrysiogenes arsenatis.

Description of Chrysiogenes arsenatis sp. nov. Chrysiogenes arsenatis (ar.sen.a'tis. M.L. gen. n. arsenatis, of arsenate, referring to the ability of the organism to reduce arsenate to arsenite). In addition to the characteristics given above in the genus description, $C$. arsenatis has the following characteristics. In liquid medium, when grown with either arsenate or nitrate, the 
organism forms large "swarms" of motile bacteria; these are not clumps, as all of the organisms are physically separate, yet they are very close together. The organism is able to grow using arsenate bound to iron oxide; swarming and motility with such a substrate are extreme. The doubling time for growth with arsenate or nitrate as the terminal electron acceptor is $4 \mathrm{~h}$. The presence of hydrogen gas stimulates the rate and extent of growth on arsenate but not on nitrate. The presence of yeast extract $(0.4 \%)$ also stimulates the rate and extent of growth.

\section{ACKNOWLEDGMENTS}

We thank T. MacAdoo (Department of Foreign Languages and Literature, Virginia Polytechnic Institute and State University) for nomenclatural advice. We also thank Ballarat Goldfields for mud samples and Kirrily Guinan for analytical assistance.

\section{REFERENCES}

1. Ahmann, D., A. L. Roberts, L. R. Krumholz, and F. M. M. Morel. 1994. Microbe grows by reducing arsenic. Nature (London) 371:750.

2. Bower, C. E., and T. Holm-Hansen. 1980. A salicylate-hypochlorite method for determining ammonia in seawater. Can. J. Fish. Aquat. Sci. 37:794-798.

3. Dowdle, P. R., A. M. Laverman, and R. S. Oremland. 1996. Bacterial dissimilatory reduction of arsenic(V) to arsenic(III) in anoxic sediments. Appl. Environ. Microbiol. 62:1664-1669.

4. Felsenstein, J. 1991. PHYLIP version 3.4. University of Washington, Seattle.

5. Fiala, G., C. R. Woese, T. A. Langworthy, and K. O. Stetter. 1990. Flexistipes sinusarabici, a novel genus and species of eubacteria occurring in the Atlantis II Deep brines of the Red Sea. Arch. Microbiol. 154:120-126.

6. Glaubig, R. A., and S. Goldberg. 1988. Determination of inorganic arsenic (III) and arsenic (III plus V) using automated hydride-generation atomicabsorption spectrometry. Soil Sci. Soc. Am. J. 52:536-537.

7. Ji, G., and S. Silver. 1995. Bacterial resistance mechanisms for heavy metals of environmental concern. J. Ind. Microbiol. 14:61-75.

8. Jukes, T. H., and C. R. Cantor. 1969. Evolution of protein molecules, p. 21-132. In H. N. Munro (ed.), Mammalian protein metabolism. Academic Press, Inc., New York.

9. Lane, D. J. 1991. 16S/23S rRNA sequencing, p. 115-175. In E. Stackebrandt and M. Goodfellow (ed.), Nucleic acid techniques in bacterial systematics. John Wiley \& Sons, Chichester, United Kingdom.

10. Larsen, N., G. J. Olsen, B. L. Maidak, M. J. McCaughey, R. Overbeek, T. J.
Macke, T. L. Marsh, and C. R. Woese. 1993. The ribosomal database project. Nucleic Acids Res. 21:3021-3023.

11. Laverman, A. M., J. S. Blum, J. K. Schaefer, E. J. P. Phillips, D. R. Lovley, and R. S. Oremland. 1995. Growth of strain SES-3 with arsenate and other diverse electron acceptors. Appl. Environ. Microbiol. 61:3556-3561.

12. Lovley, D. R., and E. J. P. Phillips. 1988. Novel mode of microbial energy metabolism: organic carbon oxidation coupled to dissimilatory reduction of iron or manganese. Appl. Environ. Microbiol. 54:1472-1480.

13. Macy, J. M., S. Lawson, and H. DeMoll-Decker. 1993. Bioremediation of selenium oxyanions in San Joaquin drainage water using Thauera selenatis in a biological reactor system. Appl. Microbiol. Biotechnol. 40:588-594.

14. Macy, J. M., T. A. Michel, and D. G. Kirsch. 1989. Selenate reduction by a Pseudomonas species: a new mode of anaerobic respiration. FEMS Microbiol. Lett. 61:195-198.

15. McGeehan, S. L., and D. V. Naylor. 1994. Sorption and redox transformation of arsenite and arsenate in two flooded soils. Soil Sci. Soc. Am. J. 58:337-342.

16. Nelson, D. C., J. B. Waterbury, and H. W. Jannasch. 1984. DNA base composition and genome size of the prokaryotic symbiont in Riftia pachyptila (Pogonophora). FEMS Microbiol. Lett. 24:267-271.

17. Oisen, G. J., R. Overbeek, N. Larsen, T. L. Marsh, M. J. McCaughey, M. A. Maciukenas, W.-M. Kuan, T. J. Macke, Y. Xing, and C. R. Woese. 1992. The ribosomal database project. Nucleic Acids Res. 20(Suppl.):2199-2200.

18. Rainey, F. A., M. Dorsch, H. W. Morgan, and E. Stackebrandt. 1992. 16s rDNA analysis of Spirochaeta thermophila: its phylogenetic position and implications for the systematics of the order Spirochaetales. Syst. Appl. Microbiol. 15:197-202.

19. Rech, S. A., and J. M. Macy. 1992. The terminal reductases for selenate and nitrate respiration in Thauera selenatis are two distinct enzymes. J. Bacteriol. 174:7316-7320.

20. Rosen, B. P., H. Battacherjee, and W. Shi. 1995. Mechanisms of metalloregulation of an anion-translocating ATPase. J. Bioenerg. Biomembr. 27:85-91.

21. Rossini, F. D., D. D. Wagman, W. H. Evans, S. Levine, and I. Jaffe. 1952. Selected values of chemical thermodynamic properties. U.S. Department of Commerce, Washington, D.C.

22. Saitou, N., and M. Nei. 1987. The neighbor-joining method: a new method for constructing phylogenetic trees. Mol. Biol. Evol. 4:406-425.

23. Thauer, R. K., K. Jungermann, and K. Decker. 1977. Energy conservation in chemotrophic anaerobic bacteria. Bacteriol. Rev. 41:100-180.

24. Voth-Beach, L. M., and D. E. Shrader. 1985. Reduction of interferences in the determination of arsenic and selenium ty hydride generation. Spectroscopy 1:60-65.

25. Woese, C. R. 1992. Prokaryote systematics: the evolution of a science, p. 2-18. In A. Balows, H. G. Trüper, M. Dworkin, W. Harder, and K.-H Schleifer (ed.), The prokaryotes, vol. 1. Springer-Verlag, New York. 